\title{
The Ecosystem Approach and Sustainable Development in Baltic Sea Marine Spatial Planning: The Social Pillar, a 'Slow Train Coming'
}

\author{
Michael Gilek, Fred Saunders and Ignè Stalmokaitè
}

While rooted in ambitions to protect the natural environment, marine spatial planning (MSP) has been heralded by a wide range of actors in policy and science alike as a policy process that could enable a balancing of various interests and policy objectives to promote sustainable marine governance and, hence, sustainable development (SD) in marine and coastal areas. ${ }^{1}$ Spurred by these aspirations, MSP is a growing global phenomenon that is increasingly being applied as a means of sustainable marine governance. ${ }^{2}$ Integral to this optimism of MSP processes as a way to achieve a more sustainable use of marine resources and territory without transcending environmental thresholds, is the notion that this is best achieved by basing MSP practices on the principles of the so-called Ecosystem(-based) Approach (EA). ${ }^{3}$

However, given this optimistic and often rather uncritical discourse on MSP and EA as a guiding principle to achieve $\mathrm{SD}$, it comes as no surprise that there

1 E.g. F Douvere, 'The Importance of Marine Spatial Planning in Advancing Ecosystem-Based Sea Use Management' (2008) 32 Mar Policy 762; European Commission, 'An integrated maritime policy for the European union' (Communication) Сом (2007) 575 final 16; HELCOMVASAB MSP Working Group, Baltic Sea broad-scale marine spatial planning principles (2010) $<$ www.helcom.fi/action-areas/maritime-spatial-planning/msp-guidelines/> accessed 24 Nov 2017 .

2 S Jay and others, 'International Progress in Marine Spatial Planning' in A Chircop and others (eds), Ocean Yearbook: Coastal and Marine Spatial Planning, vol 27 (Martinus Nijhoff Publishers 2013); HL Thomas, S Olsen and O Vestergaard (eds), Marine Spatial Planning in PracticeTransitioning from Planning (UNEP GEF-STAP 2014).

3 E.g. L Crowder and E Norse, 'Essential Ecological Insights for Marine Ecosystem-Based Management and Marine Spatial Planning' (2008) 32 Marine Policy 772; C Ehler and F Douvere, 'Marine Spatial Planning: A Step-by-Step Approach Toward Ecosystem-Based Management' (UNESCO, Intergovernmental Oceanographic Commission and Man and the Biosphere Programme, IOC Manual and Guides 53, ICAM Dossier 6 2009); S Katsanevakis and others, 'Ecosystem-Based Marine Spatial Management: Review of Concepts, Policies, Tools, and Critical Issues' (2011) 54 Ocean Coast Manag 80.

(C) MICHAEL GILEK, FRED SAUNDERS \& IGNĖ STALMOKAITE், 2019 | DOI:10.1163/9789004389984_007 This is an open access chapter distributed under the terms of the prevailing CC-BY-NC License at the time of publication. 
is an emerging academic literature that calls for more nuanced, empiricallybased and critical analyses of SD-related aspirations, including the key role given to EA principles and practices in MSP. ${ }^{4}$

Although, in this study we do not aim to review and cover the full breadth of this emerging MSP and marine governance literature, we assert that key aspects of the debate linked to MSP policy and practice relate to:i) how to analyse the complex links and compatibilities between EA and various SD dimensions/ discourses in MSP and other forms of marine governance; and ii) how conceptualisations of EA and SD in MSP are inherently contingent, so their application in practice is likely to vary widely depending on contextual factors. The second point underlines the importance of going beyond researching formal statements of MSP intent to examining how MSP is being realised in practice in various settings. The wide diversity of MSP practice creates challenges for deriving lessons learned, but nonetheless there may be commonalities across settings that provide key insights into the problems and solutions of realising different dimensions of sustainability in practice.

In terms of analysing links and compatibilities, both EA and SD are complex and multidimensional concepts influenced by norms and context. Jones, in discussing MSP and sustainability, argues that the environment can either be depicted as a competing sectoral interest ('soft sustainability') or as a special concern with recognition of ecological limits that frame development possibilities ('hard sustainability'). ${ }^{5}$ Jay et al, when talking about EA in MSP, make a similar observation but use the terms deterministic (hard) and relativistic (soft). ${ }^{6}$ Sticking with the terminology of Qui and Jones, the hard demarcation separating the two sides of the debate focuses on the degree of permissible substitutability between the economy and the environment or between 'natural capital' and 'manufactured capital', which has for a long time been a feature

4 W Qiu and P Jones, 'The Emerging Policy Landscape for Marine Spatial Planning in Europe' (2013) 39 Mar Policy 182; W Flannery and others, 'Exploring the Winners and Losers of Marine Environmental Governance/Marine spatial planning: Cui Bono? Etc.' (2016) 17(1) Planning Theory \& Practice 121; P Jones, LM Lieberknecht and W Qiu, 'Marine Spatial Planning in Reality: Introduction to Case Studies and Discussion of Findings' (2016) 71 Mar Policy 256; RV Tafon, 'Taking power to sea: Towards a Post-Structuralist Discourse Theoretical Critique of Marine Spatial Planning' (2018) 36(2) Environment and Planning C: Politics and Space 258.

5 P Jones, Governing Marine Protected Area: Resilience Through Diversity (Earthscan, Routledge 2014).

6 S Jay, T Klenke and H Janßen, 'Consensus and Variance in the Ecosystem Approach to Marine Spatial Planning: German Perspectives and Multi-Actor Implications' (2016b) 54 Land Use Policy 129 . 
of the broader sustainable development discussion ${ }^{7}$ (particularly in the environmental economics literature ${ }^{8}$ ). Both Qiu and Jones and Santos et al note that these two different conceptions of MSP are discernible in the EU's MSP institutional architecture. According to them, the EU's Integrated Maritime Policy primarily frames MSP in win-win terms (or 'soft sustainability') whereas the EU's Marine Strategy Framework Directive (MSFD) more squarely emphasises environmental protection ( or 'hard sustainability'). ${ }^{9}$ How these different conceptions of SD and EA translate to different MSP settings is an empirical question that is central to this paper. The 'hard versus soft' debate is part of a larger discursive contest over sustainable development, where there are a diverse range of views about both what should properly constitute it, and the appropriate and prudent pathways towards it.

Arguably, environmental and natural resource challenges, such as those confronting MSP, can be seen as social issues in that they closely relate to institutionalised human behaviour that determine difficult choices, such as those between environmental protection or economic development. The focus here on aspects of social sustainability fills a gap that has so far been dominated by earlier work centred on the roles of environmental protection and/or economic development in MSP. We argue here that the way that these dimensions of MSP are realised in practice are related to aspects of integration in MSP (e.g. across policy objectives and jurisdictional borders, over sectorial and stakeholder interests and knowledges). ${ }^{10}$ Hence, we hypothesize that an analytical focus on integration can provide insights into aspects of social sustainability, including participation, procedural justice, social inclusion, knowledge pluralism - all these are key processual aspects which are likely to affect distributive outcomes. However, there is a need to develop the details of such an integration-based analytical framework, as well as to explore the empirical insights for social sustainability related issues in EA and MSP processes.

In response to these ongoing discussions and calls for a contextual empirical analysis of MSP ambitions and practice we aim in this chapter to: 1) examine whether an analytical framework based on multiple MSP integration challenges provides a basis for developing a nuanced analysis of how EA relates to

$7 \quad$ W Qiu and P Jones 'The Emerging Policy Landscape for Marine Spatial Planning in Europe' (2013) 39 Mar Policy 182.

8 R Costanza and others, 'The Value of the World's Ecosystem Services and Natural Capital' (1997) 387 Nature 253.

9 W Qiu and P Jones. 'The Emerging Policy Landscape for Marine Spatial Planning in Europe' (2013) 39 Mar Policy 182; C Santos and others, 'How Sustainable is Sustainable Marine Spatial Planning? Part I - Linking the Concepts' (2014) 49 Mar Policy 59.

10 S Kidd, 'Rising to the Integration Ambitions of Marine Spatial Planning: Reflections from the Irish Sea' (2013) 39 Mar Policy 273. 
SD in MSP; 2) explore the utility of the framework for analysing social sustainability related issues in EA and MSP processes by performing case studies in some strategically chosen MSP contexts in the Baltic Sea region; 3) identify potential incompatibilities and other challenges in the interaction between EA and SD in need of further study.

The chapter is organised in the following way. First, we review the literature on integration, SD and EA in MSP to develop the integration-based analytical framework. Second, we apply the framework to analyse some strategically identified case studies of MSP in the Baltic Sea region. Finally, results are discussed with a focus on the applicability of the developed analytical framework, empirical insights on EA's challenges in MSP, and possibilities to strengthen social sustainability related issues in EA and MSP processes.

\section{$2 \quad$ Analytical Framework}

\subsection{Integration Challenges and Sustainable Development in Marine Spatial Planning (MSP)}

To achieve an analysis that moves beyond the binary soft-hard distinction of how EA and SD are conceived and practiced in MSP, we argue that it could be fruitful to base the analysis on how MSP integration challenges are addressed. It is highly likely that actors in MSP will adopt a wide variety of positions in relation to what sustainability means and how it should be implemented. How these various identities, values and interests are handled in MSP ultimately hinges on the workings of power related to how different aspects of integration are handled in specific processes, including among others, stakeholder engagement, transparency of decision-making, inclusion of different types of knowledge (attached to stakeholder engagement and influence), adoption of a cross-sectoral approach and coordination across different scales. We argue here that various aspects of integration provide analytical leverage points to interrogate key aspects of MSP planning practice, which can provide a nuanced socio-political understanding of EA and SD in different empirical settings as a complement to the soft-hard analytical distinction.

Within the MSP literature more effective Integration has been recognised as a means of addressing a variety of challenges closely related to MSP's sustainable development ambitions, such as supporting inter-sectoral decisionmaking, stakeholder engagement and cross-border interaction. ${ }^{11}$ Integration

11 ME Portman, 'Marine Spatial Planning: Achieving and Evaluating Integration' (2011) 68(10) ICES Journal of Marine Science: Journal du Conseil 2191; S Kidd and G Ellis, 'From the Land to Sea and Back Again? Using Terrestrial Planning to Understand the Process 
as a policy and analytical problem has also been discussed elsewhere - most saliently in the fields of sustainable development, ${ }^{12}$ ICZM, ${ }^{13}$ environmental policy integration, ${ }^{14}$ planning theory, ${ }^{15}$ and socio-ecological systems, ${ }^{16}$ among others.

While there are transnational directives and guidelines, MSP as a site of governance is primarily a national issue, as institutional MSP arrangements are legislated and enacted in national settings that reflect different processes, institutional setups and historic contexts that affect integration possibilities. The transnational dimension of MSP adds a further layer of complication. The need to integrate MSP over borders within transnational marine environments appears exceedingly clear, especially given the recent surge in plans to develop new types of maritime industries, such as the European Union's ambitious Blue Growth Strategy. ${ }^{17}$ This will be a challenging task in a complex transboundary context like the Baltic Sea, with its differing politico-administrative traditions, languages, marine conditions, economic interests and levels of institutionalised MSP engagement. ${ }^{18}$

of Marine Spatial Planning' (2012) 14(1) Journal of Environmental Policy and Planning 49; S Kidd, 'Rising to the Integration Ambitions of Marine Spatial Planning: Reflections from the Irish Sea' (2013) 39 Mar Policy 273; A Schultz-Zehden and K Gee, BaltSeaPlan Findings - Experience and Lessons (2013) <http://www.baltseaplan.eu/index.php/ Reports-and-Publications;809/1> accessed 24 Nov 2017; P Jones, Governing Marine Protected Area: Resilience Through Diversity (Earthscan, Routledge 2014); J Zaucha, 'Sea Basin Maritime Spatial Planning: A Case Study of the Baltic Sea Region and Poland' (2014) 50 Mar Policy 34.

12 WN Adger and A Jordan, 'Sustainability: Exploring the Processes and Outcomes of Governance' in WN Adger and A Jordan (eds), Governing Sustainability (Cambridge, Cambridge University Press 2009).

13 S Bremer and B Glavovic, 'Mobilizing Knowledge for Coastal Governance: Re-Framing the Science - Policy Interface for Integrated Coastal Management' (2013) 41(1) Coastal Management 39 .

14 A Jordan and A Lenschow, 'Policy Paper. Environmental Policy Integration: A State of the Art Review' (2010) 20(1) Environmental Policy and Governance 147.

15 G Vigar, 'Towards an Integrated Spatial Planning?' (2009) 17 (11) European Planning Studies 1571 .

16 E Ostrom, 'A General Framework for Analyzing Sustainability of Social-Ecological Systems' (2009) 325(5939) Science 419.

17 S Jay, T Klenke and H Janßen, 'Consensus and Variance in the Ecosystem Approach to Marine Spatial Planning: German Perspectives and Multi-Actor Implications' (2016b) 54 Land Use Policy 129.

18 N Tynkkynen and others, 'The Governance of the Mitigation of the Baltic Sea Eutrophication: Exploring the Challenges of the Formal Governing System' (2014) 43(1) Ambio 105. 
This imperative for transnational MSP integration is evident from both environmental and economic (arguably a sub-set of the social) perspectives. The three pillars of sustainable development are deeply interwoven, hence the incessant call for joined up approaches in MSP and other forms of environmental governance. Marine ecosystem values and processes as well as human development activities transcend national boundaries, so connectivity (which implies a form of integration) for conservation, shipping and fishing, among others needs to be considered at a localised as well as regional sea basin levels. ${ }^{19}$ Furthermore, inadequate integration in MSP has been implicated in conflicts over resources and other marine values and uses both within domestic and transnational marine space. ${ }^{20}$

Variably handling knowledge input from a range of natural and social science disciplines and stakeholders is likely to result in different constructions of what constitutes 'balance' in different marine governance settings such as MSP. $^{21}$ This is likely to be a difficult process, particularly if opposing knowledge types and related claims are linked to deep conflicts over marine resource rights. Also implicated in the knowledge integration challenge is how to ensure the transmission and sharing of knowledge among organisations involved in MSP. This may be a problem in private sector proprietary knowledge situations, where there may be commercial incentives for private sector stakeholders to closely guard knowledge/information.

Stakeholder integration relates to an overarching challenge of how to formulate and define marine environmental and use problems in such a way that all stakeholders can meaningfully contribute to formulating and resolving MSP problems. This relates to the inclusion and active involvement of stakeholders in MSP processes, their role(s), and the degree of their influence on outcomes in concrete terms (so that there are incentives for them to participate). ${ }^{22}$ Still, it has been acknowledged that there is a lack of understanding about how different strategies for stakeholder integration may work in different MSP

19 S Jay and others, 'Transboundary Dimensions of Marine Spatial Planning: Fostering Inter-Jurisdictional Relations and Governance' (2016a) 65 Mar Policy 85.

$20 \quad H$ Ritchie and G Ellis, 'A System That Works for the Sea? Exploring Stakeholder Engagement in Marine Spatial Planning' (2010) 53(6) Journal of Environmental Planning and Management 701 .

21 B Coffey and K O'Toole, 'Towards an Improved Understanding of Knowledge Dynamics in Integrated Coastal Zone Management: A Knowledge Systems Framework' (2012) 10(4) Conservation and Society 318.

22 P Jones, LM Lieberknecht and W Qiu, 'Approaches for addressing conflicts in the MESMA case studies' (2013) Deliverable 6.2 of MESMA Work Package 6 (Governance). <www .homepages.ucl.ac.uk/ ucfwpej/pdf/MESMAD6-2.pdf> accessed 24 Nov 2017. 
settings. ${ }^{23}$ Additionally, a key challenge is how to develop processes to support participation among a range of stakeholders and put measures in place to manage conflicting interests in a timely manner to inform high quality policy/ planning outcomes.

A key role of MSP is to provide a basis for marine use that takes account of current uses, while being future oriented. This ambition, to balance between consideration of current imperatives and desirable future states, is similar to the intergenerational aims and orientation of sustainable development. This aspect of integration (consolidating the now and the future) is thus critical to the role of MSP. Aside from preventing future conflicts, MSP sets a pathway to the future that will be central to the configuring of the relationship between environment and development concerns in marine contexts. Furthermore, in MSP adaptation (or adaptive capacity/management) is a key concept seen as a way of enabling the refinement of spatial management arrangements as knowledge accumulates over time within particular contexts. In the scholarly literature adaptation is heavily associated with a resilience/socio-ecological system (SES) approach. Ostrom's 2008 paper is a key contributor to the SES approach, where she argues that in complex transboundary governance contexts, such as MSP in the Baltic Sea, the key challenge is how to vertically link institutions at various levels whilst enabling enough flexibility to support adaptive management approaches (suited to local conditions) that are not overly constrained by hierarchical order. ${ }^{24}$ In this sense, the primary goal for policymakers and managers in MSP would be not to manage change, but to manage the capacity of social-ecological systems to cope with and respond to change, given highly uncertain future conditions.

As summarised in Table 6.1, we thus identify a set of seven integration challenges that correspond to how MSP objectives and processes are differently conceived and implemented. The identified integration challenges also link to specific sustainable development discourses and EA Malawi Principles (discussed further below and referred to in Table 6.1).

23 J McCann and others, Identifying Marine Spatial Planning Gaps, Opportunities, and Partners: An Assessment. (Coastal Resources Center and Rhode Island Sea Grant College Program 2014).

24 E Ostrom, Polycentric Systems as One Approach for Solving Collective-Action Problems (Indiana University 2008). 
TABLE 6.1 Summary of the analytical framework showing links between integration, sustainable development (SD) and ecosystem approach (EA). The indicated Marine Spatial Planning (MSP) implementation emphasis should be seen as representing a continuum between two notional endpoints. MSP practices in specific contexts can, hence, be situated anywhere between these endpoints.

$\begin{array}{llll}\begin{array}{l}\text { Integration } \\ \text { Dimension, emphasis }\end{array} & \begin{array}{l}\text { MSPlementation } \\ \text { institutional }\end{array} & \begin{array}{l}\text { Links to Sustainable } \\ \text { Development discourse }\end{array} & \begin{array}{l}\text { Links to Ecosystem } \\ \text { Approach principles } \\ \text { ambition }\end{array}\end{array}$

\begin{tabular}{|c|c|c|c|}
\hline Balance & $\begin{array}{l}\text { Ecological boundary } \\
\text { conditions/limits - } \\
\text { win-win }\end{array}$ & $\begin{array}{l}\text { Whether environmental } \\
\text { protection ('hard' SD) or } \\
\text { maritime development } \\
\text { ('soft' SD) is privileged }\end{array}$ & $\begin{array}{l}\text { Societal choice (1); } \\
\text { Sustainable use (4); } \\
\text { Ecosystem structure and } \\
\text { function (5); Ecosystem } \\
\text { limits (6); Balance (10) }\end{array}$ \\
\hline $\begin{array}{l}\text { Vertical } \\
\text { (territorial) }\end{array}$ & Top down - bottom up & $\begin{array}{l}\text { Strategic decision-making } \\
\text { and possibilities for more } \\
\text { 'localised' influence }\end{array}$ & $\begin{array}{l}\text { Decentralised (2); } \\
\text { Appropriate scale (7) }\end{array}$ \\
\hline $\begin{array}{l}\text { Cross-border } \\
\text { (territorial) }\end{array}$ & Disjointed - coherent & $\begin{array}{l}\text { Possibilities for a } \\
\text { harmonised approach } \\
\text { across scales, between } \\
\text { adjoining areas or areas } \\
\text { of shared interest }\end{array}$ & $\begin{array}{l}\text { Adjacent and other } \\
\text { ecosystems (3) }\end{array}$ \\
\hline $\begin{array}{l}\text { Horizontal - } \\
\text { policy/sector }\end{array}$ & Ad hoc - strategic & $\begin{array}{l}\text { Likelihood of effective } \\
\text { consideration (trade-off/ } \\
\text { synergies) of multiple } \\
\text { sustainable development } \\
\text { goals }\end{array}$ & $\begin{array}{l}\text { All relevant sectors of } \\
\text { society }(12) \text {, Sustainable } \\
\text { use (4) }\end{array}$ \\
\hline Stakeholder & $\begin{array}{l}\text { Tool for legitimacy } \\
\text { and fairness - } \\
\text { implementation } \\
\text { efficiency }\end{array}$ & $\begin{array}{l}\text { Possibility for participation } \\
\text { and deliberation and to } \\
\text { affect distributive } \\
\text { outcomes }\end{array}$ & $\begin{array}{l}\text { Societal choice (1); } \\
\text { Decentralised (2); All } \\
\text { relevant sectors of society } \\
(12)\end{array}$ \\
\hline Knowledge & $\begin{array}{l}\text { Scientific knowledge - } \\
\text { stakeholder knowledge } \\
\text { evidence - precaution }\end{array}$ & $\begin{array}{l}\text { The scope of the evidence- } \\
\text { base and opportunities } \\
\text { for a broad range of } \\
\text { stakeholders' knowledge } \\
\text { to be valued }\end{array}$ & $\begin{array}{l}\text { All forms of relevant } \\
\text { information (11); All } \\
\text { relevant sectors and } \\
\text { scientific disciplines (12) }\end{array}$ \\
\hline Temporal & Static - adaptive & $\begin{array}{l}\text { Capacity of the MSP } \\
\text { process to adopt a reflexive } \\
\text { approach over time }\end{array}$ & $\begin{array}{l}\text { Temporal scales and lag } \\
\text { effects }(8) \text {; Change is } \\
\text { inevitable (9) }\end{array}$ \\
\hline
\end{tabular}




\subsection{Ecosystem Approach and Integration in $\mathrm{MSP}$}

The Ecosystem(-based) Approach (EA) is commonly espoused as the key set of guiding principles for MSP to achieve sustainable use of marine ecosystems. ${ }^{25}$ This is reflected for instance in the EU's development of its 2014 MSP Directive. However, what this specifically means in theory and practice is not straightforward since EA, like SD, is a complex and variously conceived concept in terms of its guiding principles and how it can (or should) be implemented in marine governance processes such as MSP. ${ }^{26}$

On a general level, there is a rather consensual understanding of EA as a place-based approach to manage human activities and their cumulative risks for ecosystem services in a way that promotes sustainable use and good environmental status. ${ }^{27}$ However, this consensus quickly falls apart when it comes to what EA principles should be prioritised, especially if there is deemed to be contradictions or tensions in practice between them relating, for example, to consideration and balancing of environmental, economic and social objectives. $^{28}$

In response to this complexity and vagueness of the EA concept there have been a number of efforts to define and operationalise EA. A key document here, that is often referred to as the main foundational source, is the EA guideline of the Свр (Convention on Biological Diversity) which builds on the 12 socalled Malawi principles endorsed by the Parties to the Convention(Table 6.2). ${ }^{29}$ Similarly, EA guidelines have been developed for MSP in general, as well as for

25 Cf S Katsanevakis and others, 'Ecosystem-Based Marine Spatial Management: Review of Concepts, Policies, Tools, and Critical Issues' (2011) 54 Ocean Coast Manag 80; C Santos and others, 'How Sustainable is Sustainable Marine Spatial Planning? Part I - Linking the Concepts' (2014) 49 Mar Policy 59.

26 RD Long, A Charles and RL Stephenson, 'Key Principles of Marine Ecosystem-Based Management' (2015) 57 Mar Policy 53; E Domínguez-Tejo and others, 'Marine Spatial Planning Advancing the Ecosystem-Based Approach to Coastal Zone Management: A Review' (2016) 72 Mar Policy 115; S Jay, T Klenke and H Janßen, 'Consensus and Variance in the Ecosystem Approach to Marine Spatial Planning: German Perspectives and Multi-Actor Implications' (2016b) 54 Land Use Policy 129.

27 E.g. K McLeod and H Leslie (eds), Ecosystem-Based Management for the Oceans (Island Press 2009).

28 E.g. KK Arkem, SC Abramson and BM Dewsbury, 'Marine Ecosystem-Based Management: From Characterization to Implementation' (2006) 4 Front Ecol Environ 525; C Santos and others, 'How Sustainable is Sustainable Marine Spatial Planning? Part I - Linking the Concepts (2014) 49 Mar Policy 59; RD Long, A Charles and RL Stephenson, 'Key Principles of Marine Ecosystem-Based Management' (2015) 57 Mar Policy 53; NJI Rodriguez, 'A Comparative Analysis of Holistic Marine Management Regimes and Ecosystem Approach in Marine Spatial Planning in Developed Countries' (2017) 137 Ocean Coast Manag 185.

29 Report of the Workshop on the Ecosystem Approach (Convention on Biodiversity (CBD) 26-28 January 1998); The Ecosystem Approach (СвD Guidelines) (Secretariat of the Convention on Biodiversity, Convention on Biodiversity (СвD) 2004). 
MSP implementation in specific regional seas such as the Baltic Sea. ${ }^{30}$ There have also been attempts to distil out key EA principles by reviewing published scholarly texts. ${ }^{31}$ Still, despite these efforts, the emerging literature analysing EA in MSP processes around the world reveals a large heterogeneity in how EA is conceptually understood and operationalised in specific MSP processes at national and sub-national levels. ${ }^{32}$

In our analysis of this literature we observe that the described contentions and variability in how EA is conceptually understood and practiced can be refracted through the lens of MSP integration challenges to provide insights into key aspects of social sustainability (as summarised in Table 6.1). For example, as for MSP in general, a key contention relates to EA's role in 'balancing' environmental protection and maritime development which thus clearly links to the hard vs soft sustainability debate. However, looking beyond the dominating focus on environmental protection and/or economic development in MSP, we observe that several aspects commonly linked to notions of social sustainability are reflected in the Malawi principles (Table 6.2). In an overarching sense the most important link to social sustainability is that following the Malawi principles is expected to result in equitable sharing of benefits arising from the utilisation of resources. In pursuit of this, most importantly our analysis reveals that the set of Malawi principles relates directly to processual concerns that are likely to have a bearing on distributive outcomes, such as stakeholder and knowledge integration and associated challenges to facilitate participation, deliberation, wide knowledge exchange and learning in MSP processes (Table 6.1).

30 C Ehler and F Douvere, Marine Spatial Planning: A Step-by-Step Approach Toward Ecosystem-Based Management (UNESCO, Intergovernmental Oceanographic Commission and Man and the Biosphere Programme, Ioc Manual and Guides 53, ICAM Dossier 6 2009); HELCOM-VASAB MSP Working Group, Guideline for the implementation of ecosystem-based approach in Maritime Spatial Planning (MSP) in the Baltic Sea (2016) <http:// www.helcom.fi/action-areas/maritime-spatial-planning/msp-guidelines/> accessed 24 Nov 2017.

31 E.g. RD Long, A Charles and RL Stephenson RL, 'Key Principles of Marine EcosystemBased Management' (2015) 57 Mar Policy 53.

32 E.g. H Leslie and others, 'Learning from Ecosystem-Based Management in Practice (2015) 43 Coast. Manag. 471; E Domínguez-Tejo and others, 'Marine Spatial Planning Advancing the Ecosystem-Based Approach to Coastal Zone Management: A Review' (2016) 72 Mar Policy 115; NJI Rodriguez, 'A Comparative Analysis of Holistic Marine Management Regimes and Ecosystem Approach in Marine Spatial Planning in Developed Countries' (2017) 137 Ocean Coast Manag 185. 
TABLE 6.2 The Malawi principles for the ecosystem approach in the UN Convention on biodiversity ${ }^{\mathrm{a}}$

1. Management objectives are a matter of societal choice.

2. Management should be decentralised to the lowest appropriate level.

3. Ecosystem managers should consider the effects of their activities on adjacent and other ecosystems.

4. Recognising potential gains from management there is a need to understand the ecosystem in an economic context, considering e.g. mitigating market distortions, aligning incentives to promote sustainable use, and internalising costs and benefits.

5. A key feature of the ecosystem approach includes conservation of ecosystem structure and functioning.

6. Ecosystems must be managed within the limits to their functioning.

7. The ecosystem approach should be undertaken at the appropriate scale.

8. Recognising the varying temporal scales and lag effects which characterise ecosystem processes, objectives for ecosystem management should be set for the long term.

9. Management must recognize that change is inevitable.

10. The ecosystem approach should seek the appropriate balance between conservation and use of biodiversity.

11. The ecosystem approach should consider all forms of relevant information, including scientific and indigenous and local knowledge, innovations and practices.

12. The ecosystem approach should involve all relevant sectors of society and scientific disciplines.

a Report of the Workshop on the Ecosystem Approach (Convention on Biodiversity (CBD) 26-28 January 1998); The Ecosystem Approach (СвD Guidelines) (Secretariat of the Convention on Biodiversity, Convention on Biodiversity (СвD) 2004).

Hence, to summarise, we undertook a review of the academic literature on MSP and its links to SD and EA. Using this material, we developed a set of seven integration challenges and elaborated how they can be conceptually understood and operationalised in MSP processes (Table 6.1). The analytical framework clearly shows that EA, as defined in the Malawi principles, can be conceptually understood as a multidimensional concept that covers all identified integration challenges as well as all dimensions of SD (i.e. environmental, economic and social). The analytical framework can therefore provide a basis and structure for a multidimensional analysis of how EA is understood and 
implemented in MSP. In this respect, our analytical focus on integration could reveal important aspects of social sustainability that up until now have largely been ignored.

In the next section, we explore the utility of the framework and generate some empirical insights on how EA is variously conceived and practiced in Baltic Sea MSP processes. This is done in three distinct case studies illustrating different MSP contexts in the Baltic Sea region: i) the development of regional EA guidelines at the pan-Baltic level by the HELCOM-VASAB MSP Working Group; ii) MSP processes in Lithuania and Latvia; iii) engaging fisheries in Polish MSP. The case studies were performed during 2015-2016 as part of the BONUS BALTSPACE project and were based on an extensive set of primary data, consisting of written documentation (regulations, strategy documents, work plans, roadmaps, minutes from meetings and other relevant sources) and interviews with experts in the fields, stakeholders, policy-makers and public administrators, sector and NGO representatives and users in the different sectors. ${ }^{33}$ Moreover, data from stakeholder forums arranged by BONUS BALTSPACE, including direct observations from these meetings, have fed into how the case studies have been formulated and interpreted. The methodology and material are more extensively described elsewhere. ${ }^{34}$ The focus of the case study analysis presented here is on observations relating to stakeholder and knowledge integration - both important aspects of social sustainability.

\section{Insights on EA and SD from some Baltic Sea MSP Contexts}

\subsection{Developing EA Principles and Guidelines at the Pan-Baltic Level}

The most important institutions at the pan-Baltic level in relation to marine spatial planning are the Helsinki Commission (HELCOM), Visions and Strategies Around the Baltic Sea (VASAB) and the HELCOM-VASAB MSP Working Group (HV WG), where HELCOM targets mainly environmental protection,

33 BALTSPACE - Towards Sustainable Governance of Baltic Marine Space is an international research project on Baltic Sea Marine Spatial Planning that is being carried out $2015^{-2018}$ $<$ www.baltspace.eu>.

34 B Hassler and others, 'BONUS BALTSPACE Deliverable 2.2: Ambitions and Realities in Baltic Sea Marine Spatial Planning and the Ecosystem Approach: Policy and Sector Coordination in Promotion of Regional Integration' (2017) < www.baltspace.eu $>$ accessed 24 Sept 2018; F Saunders and others, 'BONUS BALTSPACE Deliverable D2.4: MSP as a governance approach? Knowledge integration challenges in MSP in the Baltic Sea' (2017) $<$ www.baltspace.eu $>$ accessed 24 Sept 2018. 
VASAB planning, and the HV WG has been established to bridge the border between the two in relation to MSP in the Baltic Sea region. ${ }^{35}$

MSP was identified as a key policy instrument in HELCOM's Baltic Sea Action Plan from 2007, as well as a key topic for regional coordination at the 7 th VASAB ministerial conference in Vilnius, 2009. In response to this common aim to promote MSP, the joint HELCOM-VASAB MSP Working Group (HV WG) was set up in 2009 with the objective of bringing the efforts for improved regional coordination in the two organisations closer together. In late 2010, the document Baltic Sea Broad-Scale Maritime Spatial Planning Principles was confirmed by both HELCOM and VASAB. It delineates 10 principles that are supposed to improve coordination of national MSP strategies. Notably, sustainable balancing of environmental, economic and social interests in spatial contexts provides an overarching objective, while EA is put forward as a key policy tool to reach this goal, explicitly connecting MSP with the good environmental status objectives of the EU Marine Strategy Directive.

The HV WG is made up of representatives from national ministries and agencies, invited experts, representatives from the EU administration and the VASAB and HELCOM secretariats. It was clearly established from the on-set that HV WG had no mandate to make binding decisions, but was rather intended as a transnational and trans-sector forum on MSP, with the primary aim to share experiences and increase mutual understandings. However, in addition to providing input into the discussions, it was also stated that the delegates were supposed to bring home experiences from HV WG deliberations to support implementation at national and sub-national levels.

Not long after the HVWG was set up, it became clear among the participants that it was imperative to establish a regional understanding of and norms on implementing EA in MSP. Almost all relevant EU Directives, treaties, action plans and strategies emphasise the importance of further elaborating the EA to a point where it can be forwarded in practice, which created considerable institution-based pressure on the Baltic Sea states to speed up domestic implementation, and on HV WG to provide support from a regional perspective.

After a process spanning several years and numerous meetings of the HV WG, the EA guideline that emerged was adopted by HELCOM and VASAB in 2016. ${ }^{36}$ This document outlines how EA can be used as a foundation for MSP

35 B Hassler and others, 'BONUS BALTSPACE Deliverable 2.2: Ambitions and Realities in Baltic Sea Marine Spatial Planning and the Ecosystem Approach: Policy and Sector Coordination in Promotion of Regional Integration' (2017) < www.baltspace.eu $>$ accessed 24 Sept 2018.

36 HELCOM-VASAB MSP Working Group, Guideline for the implementation of ecosystembased approach in Maritime Spatial Planning (MSP) in the Baltic Sea (2016) <http://www .helcom.fi/action-areas/maritime-spatial-planning/msp-guidelines/> accessed 24 Nov 
in the Baltic Sea region. However, its development proved to be a substantial challenge. Interviewed HV WG contributors to the guidelines, for example, reflected on the difficulties that they experienced during the formulation process in terms of 'the biggest challenge for the whole group' and 'perhaps one of the most difficult things the group has been dealing with so far'. In relation to the MSP integration challenges identified in Table 6.1, we observe that, although several challenges such as vertical, cross-border, knowledge and so on, were discernible in the development process, the overarching difficulties mostly related to balance.

Hence, substantial effort was invested in reconciling different perceptions on how balancing between environmental protection and maritime development should be conceived, articulated and ultimately transmitted as regional guidelines. Clearly, at the onset of the process it was apparent that there were clear tensions and lack of trust between HV WG participants forwarding either 'hard' or 'soft' sustainability ambitions for MSP. Although, these fundamentally different perspectives still may lead to 'some difficulties behind the scenes' as explained by one respondent linked to HVWG, we observe that collectively at the HV WG level these differences softened over time. One aspect thought to be a key factor in building a more consensual view among by HV WG membership was HELCOM's shift in its conception of how to realise EA. According to our respondents, HELCOM changed its stance from a rather strict conservation approach to focussing more on the functioning of the ecosystem. This shift, which more directly linked environmental values with socio-economic concerns, gained wide support among the HV WG and at the end the final guideline text was seen as a satisfactory compromise by those involved. Still, behind the scenes, there were different opinions on whether or not the final document provided a sufficient level of detailed practical guidance. A member of the HV WG that we talked to held the view that the consensus style decision-making of the HV WG ultimately led to compromises and inconsistencies. We see that this would have affected the substantive content of the EA guidelines and therefore likely reduced its value as a provider of strong regional directional guidance on EA in MSP. There were also expressions of disappointment on the HELCOM side about the guideline being 'really basic' and 'not very detailed and practical'. On the other hand, the perspective of VASAB and planners working with MSP was that this lack of prescriptiveness and therefore flexibility in interpretation was an advantage, since it would allow for more context-specific adjustments in, for example, different national MSP processes.

2017. Adopted by the 72nd meeting of VASAB CSPD/BSR on 8 June 2016 and approved by HELCOM HOD 50-2016 on 15-16 June 2016. 
It is also interesting to note that although the organisation of the working group allows for participation of stakeholders as observers, such involvement ultimately depends largely on the interested party's own incentive and initiative. On top of this, we observe that scepticism towards a broad stakeholder involvement prevailed in the group. Hence, although there was a common conception that stakeholder involvement might facilitate later implementation of the guidelines in national MSP, several obstacles and problems were also mentioned, in particular in terms of problems and delays linked to requirements of the group to make consensus decisions. As one respondent associated with HVWG put it 'If we involve more [stakeholders], we have more comments and more confusion'.

In summary, these observations on the process leading up to the adoption of the HELCOM-VASAB EA guideline provide insights on the main aspects of contention (i.e. linked to balance). There are also indications that a consensusdriven process such as this (i.e. the HV WG only makes decisions on the basis of consensus) might paper-over differences, which may screen conflict and power imbalances among stakeholders (remembering that the few participating NGOs are observers without full membership). This can have the effect of allowing a relatively efficient passage of the $\mathrm{EA}$ guidelines through the regional processes, while at the same time displacing conflicts in time and space to the ongoing national MSP processes. Perhaps a process that is more inclusive, less eager on consensus and prepared to deal with more conflict situations might offer more substantive guidance, particularly in relation to the importance of processual aspects of social sustainability.

A more detailed analysis of the final guideline text, also reveals some additional insights on how EA is conceived in Baltic Sea MSP and how this links to MSP integration challenges. Looking, first, at the stated definitions and key elements of EA, the document starts off by explicitly referring to the 12 Malawi principles, as well as the EA definitions of the $\mathrm{CBD} \mathrm{(СОP} 5 /$ Decision V/6, 2000) and HELCOM/OSPAR. ${ }^{37}$ Thus, in line with the CBD, EA is seen as 'a strategy for the integrated management of land, water and living resources that promotes conservation and sustainable use in an equitable way.' Furthermore, in section 5 of the guidelines, a range of key elements of MSP relating to the Malawi principles, for example, best available knowledge (Malawi principle \#11), adaptation (\# 8 and 9) and subsidiarity (\#2), are mentioned. The document also

37 Statement on the Ecosystem Approach to the Management of Human Activities (First Joint Ministerial Meeting of the Helsinki and ospar Commissions 25-26/6/2003) <www .ospar.org/about/principles/ecosystem-approach> accessed 24 Nov 2017. 
expresses a need to apply the Malawi principles in planning in an integrated way by taking into account environmental, social, cultural, economic, legal and technical perspectives. Still, the actual implementation guidance text of the document focusses mainly on environmental objectives, values, impacts, stakeholders and established procedures such as SEA, which for instance only has provision for stakeholder consultation. Thus, there is rather limited specific guidance on what parts of society should be included in stakeholder engagement, the terms of their inclusion (consultative vs. deliberative) or how to assess and to deal with epistemic or interest-based conflicts that would inevitably be encountered in MSP implementation. The document is also silent on how it will contribute to delivering greater accountability, equity or societal welfare, aside from the implicit assumption that adhering to it would deliver greater sustainability. This greater sustainability is referred to throughout the guidelines as 'sustainable use' thereby further indicating an emphasis on the ecological and economic aspects of sustainability.

Linked to knowledge integration we observe that, despite the acknowledgement of the Malawi principle \#11 on the need to base EA on all forms of relevant information, the implementation guidance text primarily focusses on scientific knowledge and neither local nor practice-based knowledge is explicitly mentioned. Furthermore, even though assessment of ecosystem services is mentioned as a new and useful approach, explicit specifications of knowledge requirements through the planning cycle relate mainly to the assessment of environmental status, values and impacts. Apart from generating information on planned or proposed uses and activities (and any impacts on ecosystem services), the implementation does not include any specific mention of the need to include socio-cultural knowledge, how to assess socio-cultural concerns and impacts or related distributional problems.

Relating to stakeholder integration, the document (section 5 ) states that 'All relevant authorities and stakeholders as well as a wider public shall be involved in the planning process at an early stage' (p. 6). In the implementation guidance, the question of what constitutes a relevant authority is only vaguely defined as 'authorities responsible for nature protection and ecosystems, and relevant authorities, NGOs and other stakeholders' (p. 13) or similar. Hence, reinforcing the impression of a primary concern in the operationalisation of stakeholder integration relating to environmental interests. When mentioned, other stakeholders and the wider public are not defined in any detail and challenges of representation or the terms of inclusion are not addressed. In guidance text explicitly giving direction on EA implementation, the role of the wider public is only mentioned once and rather meekly in relation to the need to formally consult the public (to provide information). 


\subsection{Integration, $E A$ and $S D$ in Lithuanian and Latvian MSP}

Despite the seemingly large similarities between Lithuania and Latvia as two rather small, neighbouring Baltic Sea countries with a shared recent history of being occupied by the Soviet Union, they have adopted quite different national MSP strategies, as well as interpretations of Ecosystem Approach (EA) and Sustainable Development (SD) (as summarised in Table 6.3).

In Lithuania, the Ministry of Environment (Division of Spatial Planning) was given the main responsibility for developing a national framework for MSP. The practical work was, however, performed by a consortium led by the Coastal Research and Planning Institute at Klaipeda University. On top of this, to allow some sector integration, an inter-ministerial group headed by the Ministry of Environment was formed in line with existing spatial planning procedures. Vertically, the MSP process was rather top-down with participation of local municipalities only occurring on an ad hoc basis. ${ }^{38}$ In 2015, the parliament accepted the extension of the existing Comprehensive Terrestrial Plan to include marine areas. As in the terrestrial planning, functional zoning was adopted as the main planning instrument and seven types of functional zones with dedicated primary and secondary priorities were specified.

In Latvia, the MSP strategy rolled out in a rather different way. Since MSP had been established as a policy concept in the legislation (the Spatial Development Planning Law; 2011), it could directly be used for targeted MSP purposes. In contrast to Lithuania, a broad MSP coordination group was formed in 2014 to include not only central political and administrative authorities, but also representatives from regional and local levels as well as sector stakeholders. The more active engagement of local municipalities in the centralised Latvian MSP process could partly be explained by the fact that local municipalities have been given the right to plan and manage the $2 \mathrm{~km}$ zone seawards from the coastline. Like in Lithuania, a consortium was entrusted with the actual drafting of the MSP framework, but rather than a natural science dominated research institute as in Lithuania, an environmental NGO (BEF; Baltic Environmental Forum Latvia) led the Latvian consortium. Currently, the Latvian MSP is in the process of the final round of clarifications and amendments following inputs from public and cross-sectoral consultations. The plan is anticipated to be approved by the Latvian Government by the end of 2018.

$38 \quad$ N Blažauskas and others, 'Lithuanian model case: case study report. PartSEApate.' (2014) <www.partiseapate.eu/wp-content/uploads/2014/og/Lithuanian-case-report.pdf> accessed 24 Nov 2017. 
TABLE 6.3 Basic information on the timing and setup of the Marine Spatial Planning (MSP) processes in Lithuania and Latvia. Observations linked to MSP integration challenges (cf. Table 6.2) are also summarised and explained further in the text

Lithuania

\begin{tabular}{|c|c|c|}
\hline $\begin{array}{l}\text { Time frame of } 1 \text { st } \\
\text { MSP cycle }\end{array}$ & $2012-2015$ & $\begin{array}{l}2014 \text { - adoption of plan } \\
\text { expected in } 2018\end{array}$ \\
\hline $\begin{array}{l}\text { Legal base of MSP } \\
\text { and EA }\end{array}$ & $\begin{array}{l}\text { Revised Law on Territorial } \\
\text { Planning (2013); Indirect } \\
\text { reference to EA via HELCOM- } \\
\text { VASAB MSP principles in the } \\
\text { adopted MSP document } \\
(2015)\end{array}$ & $\begin{array}{l}\text { Spatial Development } \\
\text { Planning Law (2011); } \\
\text { Direct mention of EA in } \\
\text { the Marine Environmental } \\
\text { Protection and Management } \\
\text { Law (2010) }\end{array}$ \\
\hline $\begin{array}{l}\text { General aims of } \\
\text { MSP }\end{array}$ & $\begin{array}{l}\text { Environmental protection and su } \\
\text { (albeit with different emphasis) }\end{array}$ & \\
\hline 'Balance' & $\begin{array}{l}\text { Win-Win: Pragmatic national } \\
\text { needs (e.g. OWE, MPA research) }\end{array}$ & $\begin{array}{l}\text { Sustainable use within } \\
\text { ecological limits; } \\
\text { Environmental protection }\end{array}$ \\
\hline Vertical integration & $\begin{array}{l}\text { National responsibility; } \\
\text { Municipalities obliged to } \\
\text { follow plan }\end{array}$ & $\begin{array}{l}\text { National responsibility apart } \\
\text { from municipal planning of } \\
\text { coastal zone; Cooperation with } \\
\text { local governments }\end{array}$ \\
\hline $\begin{array}{l}\text { Cross-border } \\
\text { integration }\end{array}$ & $\begin{array}{l}\text { Basic information/ } \\
\text { consultation linked to Espoo } \\
\text { Conv. and SEA Directive; } \\
\text { Low level of awareness among } \\
\text { Lithuanian NGOs }\end{array}$ & $\begin{array}{l}\text { Integrated in MSP; } 2 \text { rounds } \\
\text { of consultations; High interest } \\
\text { among Latvian NGOS }\end{array}$ \\
\hline $\begin{array}{l}\text { Stakeholder } \\
\text { integration }\end{array}$ & $\begin{array}{l}\text { Strategic sector engagement } \\
\text { as ad hoc consultations } \\
\text { linked e.g. to SEA; Additional } \\
\text { unofficial activities linked to } \\
\text { the PartiSeaPate project }\end{array}$ & $\begin{array}{l}3 \text { rounds of extensive regional } \\
\text { consultations with local } \\
\text { authorities and NGOs } \\
\text { (stocktaking, scenarios, SEA) }\end{array}$ \\
\hline $\begin{array}{l}\text { Knowledge } \\
\text { integration }\end{array}$ & $\begin{array}{l}\text { Technical and expert-driven; } \\
\text { natural science }\end{array}$ & $\begin{array}{l}\text { Process-driven knowledge } \\
\text { inclusion; focus on ecosystem } \\
\text { status and services from } \\
\text { environmental and economic } \\
\text { perspectives }\end{array}$ \\
\hline
\end{tabular}

\section{Latvia}

2014 - adoption of plan

Spatial Development

Protection and Management

. 
The Ecosystem Approach is defined in the Lithuanian Baltic Sea Environmental Protection Strategy (2010). ${ }^{39}$ The strategy sets a goal to apply an ecosystem-based approach to management of the Baltic Sea for environmental protection. The concept is defined as 'a comprehensive and integrated method to management of human activities, based on the latest available knowledge on ecosystems and their change, aiming to identify adverse impacts on the marine ecosystem and perform efficient measures for reduction of such impacts preserving integrity and sustainability of the ecosystems. ${ }^{40}$ Despite the explicitly set goal to integrate an ecosystem-based approach to manage the Baltic Sea for environmental protection, the Ecosystem Approach is only indirectly mentioned in the Lithuanian MSP document in reference to the HELCOM-VASAB broad-scale MSP principles (2010). The document states that during a development phase of Lithuanian MSP, the principles set in the above-mentioned regional guidelines were considered (the Parliament of the Republic of Lithuania 2015). In addition, a following reference is given: 'the planning process shall take into account environmental, economic and social interests in a wider Baltic Sea regional framework and shall be in line within the limits of the Baltic Sea ecosystem services.41 Despite an implicit mentioning of ecosystem services in a wider Baltic Sea regional context, it is not entirely clear to what extent, if any at all, the principles of an ecosystem approach were integrated in the actual MSP planning activities in Lithuania.

In contrast, EA is explicitly defined in the Latvian Marine Environmental Protection and Management Law (2010 and came into force from 1 Jan 2011) as: 'comprehensive, scientifically substantiated and integrated approach to management of human activity to identify adverse impacts on the marine ecosystem and perform efficient measures for reduction of such impacts preserving integrity and sustainability of the ecosystem, ${ }^{42}$ This definition has been used

39 The Resolution of the Government of the Republic of Lithuania on the Approval of the Baltic Sea Environmental Protection Strategy, August 25, 2010, No. 1264.

$40 \quad$ Ibid., 6.

41 Ibid., 4.

42 Marine Environmental Protection and Management Law (Parliament of the Republic of Latvia 2010) (English version, the document consolidated by State Language Center). The Spatial Development Law (2011), however, does not explicitly mention EA. Instead the overlapping planning principle of 'sustainability' is referred to as 'spatial development is planned in order to preserve and form a good environmental quality, balanced economic development, rational use of natural, human and material resources, development of the natural and cultural heritage for the present and next generations', Spatial Development Planning Law 2011 (Parliament of the Republic of Latvia 2011). 
and applied both in the Latvian MSP process and when developing the MSP Strategic Environmental Assessment (SEA) methodology. ${ }^{43}$

Concerning the MSP integration challenge of 'Balance', the Lithuanian MSP process sets as a goal 'to maintain balance between economic development and good ecological status. ${ }^{44}$ In addition, sustainable development is emphasised as one of the key MSP planning principles to ensure 'a balance between regional economic development, social well-being and healthy or (and) resilient ecosystem of the Baltic Sea: ${ }^{45}$ The wording in these ambitions implies that the marine environment is a sectoral interest to be considered alongside other maritime sectors. In other words, the Lithuanian MSP appears to be adopting a 'soft' sustainability approach that looks to 'balance' the needs of different marine sectors without any 'hard' preferential treatment of environmental concerns. Comments made by several interviewed respondents in the case study also quite directly inferred a 'soft' sustainability approach in Lithuania.

On the contrary, a number of actors involved in the Latvian MSP emphasised that environmental protection is a top priority on the national MSP agenda. In line with this, MSP was elaborated by explicitly developing and applying an ecosystem-based methodology, which involved mapping provisioning, regulating and cultural services to assess the impacts of various sea use scenarios and proposed permitted uses of Latvian marine areas. In developing this EA, the descriptors for Good Environmental Status from the EU MSFD were explicitly drawn on in order to 'assess the significance of human pressure'. This indicates an approach where perceived ecological limits informed MSP, presumably with the aim to make sure that ecosystem services and values are not subjected to threshold level pressures from proposed use of marine areas and resources. This 'hard' sustainability approach also underpins the argument presented by a respondent from the regional governmental authority, Kurzeme planning region, that 'Latvia has a strong tradition on nature protection. Meanwhile, the concept of Blue Growth is relatively new and people are not aware of it'.

The process of stakeholder involvement in Lithuania was twofold. On the one hand, the planning process followed official procedures of stakeholder involvement (e.g. public announcement of the beginning of the planning

43 Ministry of the Environmental Protection and Regional Development, Maritime Spatial Plan for territorial sea and exclusive economic zone of the Republic of Latvia (2015) Environmental report, 1st draft; Ministry of the Environmental Protection and Regional Development, Maritime spatial plan for the internal marine waters, territorial waters and exclusive economic zone of the Republic of Latvia (2016).

44 Comprehensive Plan of the Territory of the Republic of Lithuania Complemented by Marine Spatial Solutions (Parliament of the Republic of Lithuania 2015 No. 12-1781) 2.

Ibid., 4. 
process, official meetings with the inter-ministerial group (comprised of vice ministers of the respective key ministries) and MSP working group (comprised of the developers of the plan and the respective people from the Ministry of Environment). Broader stakeholder involvement was not seen as necessary. Instead, the public hearing processes of the prepared strategic environmental assessment (SEA) was considered to be a very good opportunity for other actors (NGOs, local authorities) to get involved in the process. In addition, Lithuanian planners organised one transboundary consultation with Latvia as part of the Lithuania MSP SEA. Some face-to-face meetings, roundtables and other workshops were also organised in a strategic way through direct contact with targeted sectors (Port of Klaipeda, Navy, Maritime Safety Administration) in order to find solutions to certain problems/potential conflict situations identified by the planners. The majority of face-to-face meetings and workshops on national and international level were, however, performed as part of the EUfunded project PartiSeaPate. ${ }^{46}$ While these project-based activities, according to a MSP planner, were not part of the so-called official MSP process, the organised sectoral and transboundary discussions were seen to facilitate the MSP planning process in general.

In Latvia, a Public Participation Strategy was prepared in order to ensure that all relevant actors are brought in at an early stage of the planning process. ${ }^{47}$ During the first phase of the MSP process in Latvia, three open regional meetings were organised in different coastal areas in March 2015. During these meetings, the discussion centred on the MSP process, the current situation, preliminary results from the stocktaking and Baltic Sea targets related to environmental processes and values. During the second stage of the planning process alternative MSP scenarios were developed which were presented in a second round of regional workshops, which were open to all stakeholders and public. The planners also organised several individual sectoral consultations in the spring and autumn of 2015 to identify and clarify sectoral need and to get input on a draft MSP. Key sectors such as shipping, energy, tourism and recreation, fisheries, underwater cultural heritage, nature conservation and others sectors relevant for sea uses were consulted. Some of the sectoral meetings were multisector rather than just between the MSP planners and the target sector. For example, during the meetings with the port authorities and the offshore wind energy (OWE) sector representatives from

$46<$ <ww.partiseapate.eu> accessed 24 Nov 2017.

47 K Veidemane, A Ruskule and S Sprukta, Development of a Maritime Spatial Plan. The Latvian Recipe $5^{6}$ pp. (2017) <www.balticscope.eu/events/final-reports/> accessed 24 Nov 2017. 
the environmental sector were also invited to introduce the concept of 'good environmental status'. The environmental sector did not meet any major objections from other sectors during these meetings.

Hence, looking at knowledge integration in the Latvian MSP process, broad non-expert and expert involvement and input was sought in using the EA to systematically support decisions by working through relationships between existing marine values and processes spatially linked to actual and proposed uses. While participation of broader publics was framed in less ambitious terms than stakeholder participation (i.e. as receivers of information and opportunities for consultation), the Latvian MSP process seems to have provided opportunities from an early stage and onward for significant 'place-based knowledge' input by coastal municipalities and government, as well as non-government sectoral interests. This contrasted with the Lithuanian approach to the development of its national MSP, where there was very little scope given for wider engagement and knowledge integration, and when it did occur it was primarily as information/consultation at the final stage of plan development.

The outcomes of the respective MSP processes in Lithuania and Latvia are far from clear since Lithuania is still preparing the implementation program of the adopted MSP and Latvia is still in the process of the adoption of its MSP. However, the way that the MSP priorities were set and organised suggests that there are clear differences to interpreting EA and SD in terms of balance, stakeholder inclusion and knowledge integration.

\subsection{Knowledge and Stakeholder Integration in Polish MSP: The Case of Fisheries}

As described above, at a Baltic-wide level much emphasis has been put on the role of natural science as the dominant evidence-base underpinning MSP while much less effort has been invested in how to integrate different forms of knowledge into MSP. Incorporating different forms of socio-cultural knowledge within an EA framework more broadly has posed particular problems for MSP, both in the Baltic and elsewhere. Here, we explore this issue in the Polish case, with a particular focus on fisheries.

The legal basis for MSP in Poland has been in place since 2003. Coordination is undertaken by the Maritime Administration with operational responsibility shared between several sectoral-based ministries. ${ }^{48}$ During 2008 to 2011, Poland prepared three maritime pilot plans covering some of its maritime space. Also across Polish sea space, extensive stocktaking has been undertaken

48 J Zaucha and others, 'BONUS BALTSPACE Deliverable 2.1: Baseline-Mapping and Refined Case Study Design' (2016) < www.baltspace.eu> accessed 24 Nov 2017. 
as well as detailed studies on current uses, possible future uses and potential conflicts. ${ }^{49}$ The Ecosystem Approach has been explicitly applied throughout the development of these preparatory materials which will be drawn on to inform the work of developing the national maritime spatial plan, which began in mid-2016. ${ }^{50}$

Poland has experienced significant problems in trying to engage with fishers in MSP during the national MSP preparatory work described above. At the core of the problem has been a concern by fishers that their knowledge is not valued or respected and therefore they can have little influence in MSP processes as indicated in the following quote:

[Decision-makers] do not value the opinion of [fishers] who use the sea since tens of years because we are not well-organized and do not have unlimited funds. And, unfortunately, we lose due to lack of money and they [the offshore energy sector] win. [Polish fisher]

Polish fishers also accused scientists involved in stock-taking work (i.e., mapping of conditions, values and uses (users) in Polish marine space) in preparation for developing the national Polish MSP of using scientific jargon with stakeholders in a way that restricts their capacity to engage in meaningful dialogue, as indicated in the following quotes from fishers:

[Scientific results] were presented, some numbers were shown but it was all difficult to understand. It was like a professor is giving a lecture to students who are not listening to him. [Polish fisher]

Scientists are careless how to communicate their knowledge. They cannot present it in a way that fishers expect. They show charts, drawing and bars, but what is the conclusion? [Polish fisher]

The fishers in part were responding to their previous experience in interacting with scientists over marine governance issues.

The natural scientists involved in MSP in Poland who were interviewed were not fully aware of how their work is being perceived by the fishers, however,

49 Ibid.

5o J Zaucha, 'Sea Basin Maritime Spatial Planning: A Case Study of the Baltic Sea Region and Poland' (2014) 50 Mar Policy 34; J Zaucha and others, 'BONUS BALTSPACE Deliverable 2.1: Baseline-Mapping and Refined Case Study Design' (2016) <www.baltspace.eu> accessed 24 Nov 2017. 
they saw their role as a provider of objective facts to underpin MSP decisionmaking, while recognizing that there are likely to be divergent views on this:

I am aware that sometimes fishers say that they can see on the echosounder that [the] sea is full of fish but they cannot fish [because of conservation measures]. The fact that there is plenty of fish in one place does not imply that there are many of them in the whole Polish marine areas, and that it is possible to increase quotas. And here I trust scientific knowledge coming from different disciplines. This knowledge is extremely important as planners can have their subjective opinions and fishers might also have different expectations. And all these [conflicting expectations] need to be considered. [Polish scientist]

Among fishers and scientists and other stakeholders, different views on casual relationships, responsible agents and solutions to these problems go to the heart of the current knowledge schism affecting M SP in Poland, which has clear links to EA applications more widely. For example, well before the advent of MSP, near-shore fishers held strong views that conservation of seals and cormorants negatively affected their livelihoods. ${ }^{51}$ While it has been shown that there are areas where such an effect is discernible, there is little scientific evidence backing the broader spatial validity of this claim. When fishers demand additional research (because they do not accept the current scientific understanding), it is not always abundantly clear how such research should be conducted or what it should be targeted at finding out. Perhaps this is not a MSP stakeholder concern that can be addressed with more scientific knowledge, but rather reflects deeper reservations about feelings of vulnerability about fishers' rights in the face of newcomers and what they may see as the strengthening of some actors' positions in marine governance, e.g., conservation and energy sector. Putting aside the sustainability concerns of socio-economic exclusion, the example of the Polish fisheries in MSP shows that EA, in adopting an evidence-based approach, ought to more fully recognise the challenges raised by scientific uncertainty/disagreement and the importance of developing approaches to help reduce and address such challenges. Such an approach would establish transparent ground rules for interpretation and application of the precautionary principle and how to value different forms of knowledge in decisionmaking under conditions of uncertainty. As Johnsen and Hersoug suggest,

$5^{1} \quad$ M Michałek and L Kruk-Dowgiałło, 'Konsultacje społeczne jako element planowania ochrony obszarów natura 2000 na przykładzie zatoki puckiej, Inżynieria Ekologiczna' (2015) 42 Ecological Engineering 95. 
fishers are likely to possess more knowledge about conditions at a localised scale than scientific knowledge. ${ }^{52}$ Griffin makes a similar point that knowledge conflicts (or difficulties in integrating knowledge systems) are often attributable to questions of scale, particularly where it is claimed that scientific knowledge has not adequately considered local knowledge and experience often due to concerns over knowledge credibility or the blurring of the fact/value distinction..$^{53}$ The considered inclusion of such localised knowledge may also work in instances of overt and deeply entrenched conflict to moderate negative attitudes towards participating in MSP. Knowledge integration involves engaging in bridging between all forms of knowledge. This may not necessarily mean neutralising power-related imbalances between different forms of knowledge such as those discussed above in the Polish MSP, but rather seeing differences as an inevitable part of bridging processes where deliberation is required to assess their relevance, meanings and interpretations.

This analysis has shown that an important aspect of the knowledge integration challenge in MSP and the EA more broadly centres on how to mix scientific knowledge with the knowledge politics of stakeholder participation in a way that both supports social inclusion and improves the evidence-base underpinning decisions.

\section{Concluding Remarks on Applying an Integration-based Analytical Framework}

In this chapter, we have argued for the need to develop an approach to analyse the complex links between an Ecosystem Approach (EA) and sustainable development (SD) in marine spatial planning (MSP). We, furthermore, hypothesized that a focus on MSP integration challenges such as stakeholder and knowledge integration could provide a basis for generating nuanced insights into the complex interrelationships between EA and SD in general, and on social sustainability related issues in particular.

In this final section, we reflect on the utility and applicability of the developed integration-based analytical framework in the performed case studies, what key empirical insights were attained, and answer the question, whether

$5^{2} \quad$ JP Johnsen and B Hersoug, 'Local Empowerment Through the Creation of Coastal Space?' (2014) 19(2) Ecology and Society 60.

53 The claim that actors are conflating how the world is (fact) versus how it ought to be (values). L Griffin, 'Scales of Knowledge: North Sea Fisheries Governance, the Local Fisherman and the European Scientist' (2009) 18(4) Environmental Politics 557. 
identified challenges linked to social sustainability can be addressed as part of EA or through development of a complementary Socio-cultural Approach?

First, in relation to the utility of the integration-based analytical approach and key empirical insights, it is obviously premature to draw any definitive or overarching conclusions on the merits of the developed framework, especially given the complex contextual nature of the issues being analysed and the few cases included in this study. Still, in reflecting on the case study outcomes, we find that the integration-based approach provided key insights on EA and SD in MSP that were more detailed and processual in nature than what the more static soft-hard sustainability distinction would have provided. That is, even though our case studies of some Baltic Sea MSP contexts revealed that diverging opinions on how to balance or give different preference to environmental conservation and economic development (i.e. the soft-hard debate) were a key issue of contention in all case studies, it was only by looking at MSP integration challenges that we were able to gain insights into how the hard-soft debate also included social dimensions outside of crude economic or environmental preferencing. This can, for example, be observed in the Polish case, where fishers' lack of trust in the science-based MSP process and their feelings of vulnerability in relation to new forms of sea-space use (e.g. offshore wind energy) exposes a more fine-grained picture consisting of conflicting knowledge claims and visions for what type of development and social inclusion should be strived for. The Lithuanian/Latvian case showed deeply contrasting approaches to placing boundaries around sectoral involvement in MSP and indeed in stakeholder engagement in general. Drawing on the analytical framework enabled us to compare both countries to get greater insights and understandings of how institutional processes affected or were influential in the formation of MSP outcomes. More specifically, in Lithuania the involvement of key sectoral actors resulted in a MSP that tends towards strategic blue growth strategies whereas Latvia, through its more extensive stakeholder involvement, more explicitly addresses environmental protection concerns.

We also find that an analysis of MSP integration challenges and, in particular, social sustainability related issues, may provide better insights into the legitimacy of MSP processes, but also potentially into how these processes affect socio-ecological outcomes. For example, in the HV WG case, the consensus-driven process to develop EA guidelines was characterised by a quite instrumental framing of stakeholder integration. Furthermore, despite acknowledging the Malawi principle \#11 of the need for all relevant forms of information in EA, the guideline document does not explicitly mention local or practice-based knowledge integration. Instead, evidence requirements are mostly linked to scientific knowledge on environmental status, values and 
impacts. Similar challenges for knowledge integration were observed relating to the inclusion of fishers' and other stakeholders' knowledge in the Polish and Lithuanian MSP processes. Although such instrumental and science-based framings of stakeholder and knowledge integration could allow a relatively efficient development of guidelines and plans, it might paper-over differences, and thereby merely shift conflicts in time and space to, for example, the implementation of national plans or the management of transboundary activities such as offshore fisheries or maritime transports.

To summarise this part of the conclusions, we argue that analysis of MSP integration challenges provides a means for illuminating how EA and SD are variously conceived and practiced in MSP. Obviously, additional studies are needed to further develop and validate the approach by, for example, considering a more comprehensive set of integration challenges and MSP contexts than presented here. Still, the insights gained here highlight the potential of the integration approach to disclose aspects of social sustainability (e.g. participation, social inclusion, knowledge pluralism) and to add important processual understandings of how MSP (as well as associated EA and SD discourses) unfold in particular MSP contexts. This involves, for example, possibilities to analyse how balance between policy objectives for environmental conservation, sustainable use and benefit sharing is arrived at. In concrete situations, these goals cannot be given equal priority, so to understand how these are weighted in MSP we need to generate insights into institutional arrangements and how policy goals are forwarded and negotiated. Here, a focus on integration as a multidimensional analytical concept is explicitly able to show how trade-offs, preferences, exclusions, inclusions, and synergies play out in MSP practice. This then also offers opportunities for better understanding, reflexivity and evaluation, thereby enhancing MSP capacity to effectively undertake long-term adaptation. Furthermore, revealing how choices are made between conservation, sustainable use and benefit sharing has broader democratic benefits in terms of transparency, accountability etc. In a general sense, a renewed emphasis on the social in EA may also support a shift from focussing on ecological or economics concerns (sometimes in isolation) to adopting a more comprehensive approach to SD, which better encapsulates notions of human well-being.

Second, with respect to possibilities to develop the social pillar in EA and MSP, the case study results from the Baltic Sea clearly show discrepancies between stated EA principles relating to social sustainability and MSP in practice. Thus, while EA is commonly defined as a comprehensive sustainable development approach with reference to CBD and the Malawi principles (e.g. in the HVWG guidelines), it is primarily concerned with ecological and economic values and 
trade-offs between these in the specific HV WG guidelines and in the observed national MSP processes in Lithuania, Poland and Latvia. We acknowledge that social and cultural aspects are mentioned and included to some extent in the Latvian MSP process, but the assessment and consideration of such concerns are substantially addressed by linking them to the importance of specified ecosystem services for particular stakeholder groups such as the marine tourism sector. Hence, although the Latvian MSP process can be seen as a step in the right direction, the sector-based ecosystem services approach chosen does not yet come close to considering the full social pillar as discussed in the academic debate (i.e. comprehensive social inclusion and deliberation and knowledge pluralism). ${ }^{54}$ We also argue that the ecosystem services approach, although providing a promising way to consider interactions between environmental and economic interests, is fundamentally problematic in its application of social and cultural issues because of the inherently contingent and diverging evaluation and prioritisation of socio-cultural value by various stakeholders and among the general public. ${ }^{55}$

In summary, the above findings show, to borrow Bob Dylan's famous lyrics, that the social pillar in the Baltic Sea EA and MSP implementation is, at best a 'slow train coming'. However, the timetable of this development of a social pillar, as well as actual possibilities of reaching close to a final destination of a comprehensive SD approach in Baltic Sea MSP is presently unclear. Key questions are thus, whether something can be done to speed up the present development or whether there is a possibility for a more fundamental re-routing to an alternative and faster track?

While probably difficult and time consuming to achieve, we do see several possibilities for enhancing social inclusion and knowledge pluralism in EA and MSP processes by developing more detailed guidance and requirements at EU, pan-Baltic and national levels. One key issue is a need to better assess and address social/cultural concerns, values and impacts linked to various scenarios. The need for, as well as the current under-emphasis on, social assessment is commonly pinpointed in the wider academic literature on environmental governance as a means to improve the evidence-base underpinning decisions and to promote social inclusion. ${ }^{56}$ Social mapping, including intensive participatory processes, linked to environmental planning and development initiatives

54 M Boström, 'A Missing Pillar? Challenges in Theorizing and Practicing Social Sustainability' (2012) 8(1) Sustainability: Science, Practice, and Policy 3.

55 N Small, M Munday and I Durance, 'The Challenge of Valuing Ecosystem Services That Have No Material Benefits' (2017) 44 Global Environmental Change 57.

56 O Renn, Risk Governance: Coping with Uncertainty in A Complex World (Earthscan 2008). 
is also a more common approach in the global south than in the global north. ${ }^{57}$ Hence, we argue that such strengthened focus on social mapping of sea space in MSP can improve the possibilities of the ecosystem services approach to connect particular ecosystem values/services to communities - not just in broad sectoral stakeholder terms, but in a way that acknowledges and recognises the place-based interests and knowledge of different heterogeneous communities. Such mapping could also reveal insights into social interests/ concerns, socio-cultural/local values and knowledge, enhance understanding of important connections between land and sea and increase the resolution and precision of MSP processes. We believe that this can be a particularly important approach when confronting entrenched conflicts or intensively used sea spaces as found, for example, between fishers and planning authorities in the Polish case and elsewhere. A social mapping approach may also, in a general sustainable development sense, be beneficial as a way of connecting particular ecosystem attributes with human wellbeing.

In addition, relating to knowledge pluralism and social inclusion, we believe that there are lessons to be learned from European fisheries management on how the role of science and knowledge integration has taken a democratic turn' in the last decades. ${ }^{58}$ Fisheries management is, like MSP, a complex and conflictual societal issue associated with significant scientific uncertainty that has a strong focus on science support in policy development and management. In the fisheries sector it can, thus, be observed that science support via the international scientific organisation The International Council for the Exploration of the Sea (ICES) successively has opened up from a system built on natural sciences and a clear separation of science and policy, to a more interdisciplinary and inclusive approach acknowledging and managing also lack of knowledge and other forms of uncertainty. This development follows arguments made by proponents of the so-called 'post-normal science' concept and was catalysed by a long history of problems in reaching policy objectives to keep fishing pressures at sustainable levels and infected disagreements between e.g. fishers and scientist on how to interpret the knowledge and uncertainties at hand. ${ }^{59}$ Although this shift in fisheries management was

57 SJ Breslow and others, 'Conceptualizing and operationalizing human wellbeing for ecosystem assessment and management' (2016) 66 Environmental Science \& Policy 250.

58 F Saunders, M Gilek and S Linke, 'Knowledge for Environmental Governance: Probing Science-Policy Theory in the Cases of Eutrophication and Fisheries in the Baltic Sea' (2017) 6 Journal of Environmental Planning and Management 769.

59 SO Funtowicz and JR Ravetz, 'Science for the Post-Normal Age' (1993) 25(7) Futures 739; P Spruijt and others, 'Roles of Scientists as Policy Advisers on Complex Issues: A Literature Review' (2014) 40 Environmental Science \& Policy 16; F Saunders, M Gilek and S Linke, 'Knowledge for Environmental Governance: Probing Science-Policy Theory in the Cases 
neither unproblematic nor devoid of conflict, ${ }^{60}$ recent studies indicate that both management of knowledge conflicts and goal achievement have improved in several respects in the new more 'democratic' system. ${ }^{61}$ Hence, we argue that there are good possibilities to reach similar positive outcomes in MSP processes by building on post-normal science thinking and lessons learned from fisheries management. This could possibly promote a more inclusive and grounded stakeholder participation and knowledge integration, while still filling the explicit EA and MSP objective of basing the planning on the best available scientific knowledge. ${ }^{62}$

Returning a final time to the train analogy, there is, however, a significant risk that the above discussed ideas for incremental change linked to the development of EA practices will not get the 'social pillar train' to its final destination (i.e. to a comprehensive sustainable development approach in MSP). There is, for example, a risk that track-dependencies and institutional inertia will hinder a further development of the social pillar as part of the EA. After all, at least in terms of marine governance in the Baltic Sea and elsewhere, the Ecosystem Approach was first picked up and promoted as an environmental approach by, for example, HЕLCOM, and other environmentally-focussed actors. ${ }^{63}$ Hence, although EA's application in MSP processes in theory can be widened to become a comprehensive SD approach in line with its definition in СвD and the Malawi principles, we speculate that this will be hard to achieve in the short term. As an alternative, we therefore forward the possibility of developing a parallel and complementary 'Socio-cultural Approach' (SA) that would focus primarily on how issues such as participation, procedural justice, social inclusion and knowledge pluralism could be focussed and promoted in MSP. It is beyond the scope of this chapter to develop specific ideas for how such a SA could be defined and practiced in MSP. However, we believe that SA similar to EA should be a science-based approach that in line with ideas on post-normal science builds on stakeholder involvement, wider knowledge inclusion and acknowledgement of fundamental uncertainties.

of Eutrophication and Fisheries in the Baltic Sea' (2017) 6 Journal of Environmental Planning and Management 769 .

6o DC Wilson, The Paradoxes of Transparency: Science and the Ecosystem Approach to Fisheries Management in Europe (Amsterdam University Press 2009).

61 F Saunders, M Gilek and S Linke, 'Knowledge for Environmental Governance: Probing Science-Policy Theory in the Cases of Eutrophication and Fisheries in the Baltic Sea (2017) 6 Journal of Environmental Planning and Management 769.

62 Statement on the Ecosystem Approach to the Management of Human Activities (First Joint Ministerial Meeting of the Helsinki and OSPAR Commissions 25-26/6/2003) <www .ospar.org/about/principles/ecosystem-approach> accessed 24 Nov 2017.

Ibid. 
Rounding out this chapter, our concluding reflection is that in order to realise the EA Malawi principles in MSP practice, a concerted and systematic approach will need to be adopted that is true to the principles, but sensitive to local contextual settings. This effort can be supported by paying greater attention to how to fairly and effectively consider socio-cultural knowledge and interests in MSP, through social mapping exercises that link human welfare with marine space beyond blunt sector-based interest perspectives and conducting meaningful deliberative engagement with a wider array of stakeholders that does not avoid conflict, but enables differences to be openly expressed and taken into consideration in MSP processes.

\section{5 Acknowledgements}

We would like to thank collaborators from the BONUS BALTSPACE project Nerijus Blažauskas, Anne Luttmann and Joanna Piwowarczyk (and their respective case study teams) for their contributions to the case study analyses presented here. All respondents are also thanked. The authors were funded by the Foundation for Baltic and East European Studies (2186/3.1.1/2014) and by воNUS (Art 185), funded jointly by the EU and the Swedish Research Council FORMAS.

\section{Statutes}

Marine Environmental Protection and Management Law (Parliament of the Republic of Latvia 2010).

Spatial Development Planning Law 2011 (Parliament of the Republic of Latvia 2011).

\section{Bibliography}

\section{Books}

Jones P, Governing Marine Protected Area: Resilience Through Diversity (Earthscan, Routledge 2014).

McLeod K and Leslie H (eds), Ecosystem-Based Management for the Oceans (Island Press 2009).

Ostrom E, Polycentric Systems as One Approach for Solving Collective-Action Problems (Indiana University 2008). 
Renn O, Risk Governance: Coping with Uncertainty in A Complex World (Earthscan 2008).

Wilson DC, The Paradoxes of Transparency: Science and the Ecosystem Approach to Fisheries Management in Europe (Amsterdam University Press 2009).

\section{Official Publications}

Blažauskas N and others, 'Lithuanian model case: case study report. PartSEApate.' (2014) <www.partiseapate.eu/wp-content/uploads/2014/og/Lithuanian-case -report.pdf $>$ accessed 24 Nov 2017.

Comprehensive Plan of the Territory of the Republic of Lithuania Complemented by Marine Spatial Solutions (Parliament of the Republic of Lithuania 2015 No. 121781) 2.

Ehler C and Douvere F, 'Marine Spatial Planning: A Step-by-Step Approach Toward Ecosystem-Based Management' (UNESCO, Intergovernmental Oceanographic Commission and Man and the Biosphere Programme, Ioc Manual and Guides 53, ICAM Dossier 6 2009).

European Commission, 'An integrated maritime policy for the European union' (Communication) Сом (2007) 575 final 16.

HELCOM-VASAB MSP Working Group, Baltic Sea broad-scale marine spatial planning principles (2010) <www.helcom.fi/action-areas/maritime-spatial-planning/msp -guidelines/> accessed 24 Nov 2017.

H E LCOM-VASAB MSP Working Group, Guideline for the implementation of ecosystembased approach in Maritime Spatial Planning (MSP) in the Baltic Sea (2016) <http://www.helcom.fi/action-areas/maritime-spatial-planning/msp-guidelines/> accessed 24 Nov 2017.

Ministry of the Environmental Protection and Regional Development, Maritime Spatial Plan for territorial sea and exclusive economic zone of the Republic of Latvia (2015) Environmental report, 1st draft.

Ministry of the Environmental Protection and Regional Development, Maritime spatial plan for the internal marine waters, territorial waters and exclusive economic zone of the Republic of Latvia (2016).

Report of the Workshop on the Ecosystem Approach (Convention on Biodiversity (CBD) 26-28 January 1998.

Schultz-Zehden A and Gee K, BaltSeaPlan Findings - Experience and Lessons (2013) $<$ http://www.baltseaplan.eu/index.php/Reports-and-Publications;809/1> accessed 24 Nov 2017.

Statement on the Ecosystem Approach to the Management of Human Activities (First Joint Ministerial Meeting of the Helsinki and ospar Commissions 2526/6/2003) <www.ospar.org/about/principles/ecosystem-approach> accessed 24 Nov 2017. 
The Ecosystem Approach (свD Guidelines) (Secretariat of the Convention on Biodiversity, Convention on Biodiversity (CBD) 2004).

Thomas HL, Olsen S and Vestergaard O (eds), Marine Spatial Planning in Practice Transitioning from Planning (UNE P GEF-STAP 2014).

Veidemane K, Ruskule A and Sprukta S, Development of a Maritime Spatial Plan. The Latvian Recipe $5^{6}$ pp. (2017) <www.balticscope.eu/events/final-reports/> accessed 24 Nov 2017.

\section{Book Chapters}

Adger WN and Jordan A, 'Sustainability: Exploring the Processes and Outcomes of Governance' in Adger WN and Jordan A (eds), Governing Sustainability (Cambridge, Cambridge University Press 2009).

Jay S and others, 'International Progress in Marine Spatial Planning' in A Chircop and others (eds), Ocean Yearbook: Coastal and Marine Spatial Planning, vol 27 (Planning, Martinus Nijhoff Publishers 2013).

\section{Journal Articles}

Arkema KK, Abramson SC and Dewsbury BM, 'Marine Ecosystem-Based Management: From Characterization to Implementation' (2006) 4 Front Ecol Environ 525.

Boström M, 'A Missing Pillar? Challenges in Theorizing and Practicing Social Sustainability' (2012) 8(1) Sustainability: Science, Practice, and Policy 3.

Breslow SJ and others, 'Conceptualizing and operationalizing human wellbeing for ecosystem assessment and management' (2016) 66 Environmental Science \& Policy 250.

Bremer S and Glavovic B, 'Mobilizing Knowledge for Coastal Governance: ReFraming the Science - Policy Interface for Integrated Coastal Management' (2013) 41(1) Coastal Management 39.

Coffey B, O’Toole K, 'Towards an Improved Understanding of Knowledge Dynamics in Integrated Coastal Zone Management: A Knowledge Systems Framework' (2012) 10(4) Conservation and Society 318.

Costanza R and others, 'The Value of the World's Ecosystem Services and Natural Capital' (1997) 387 Nature 253.

Crowder L and Norse E, 'Essential Ecological Insights for Marine Ecosystem-Based Management and Marine Spatial Planning' (2008) 32 Marine Policy 772.

Domínguez-Tejo E and others, 'Marine Spatial Planning Advancing the EcosystemBased Approach to Coastal Zone Management: A Review' (2016) 72 Mar Policy 115.

Douvere F, 'The Importance of Marine Spatial Planning in Advancing EcosystemBased Sea Use Management' (2008) 32 Mar Policy 762.

Flannery W and others, 'Exploring the Winners and Losers of Marine Environmental Governance/Marine spatial planning: Cui Bono? Etc.' (2016) 17(1) Planning Theory \& Practice 121. 
Funtowicz SO and Ravetz JR, Science for the Post-Normal Age' (1993) 25(7) Futures 739. Griffin L, 'Scales of Knowledge: North Sea Fisheries Governance, the Local Fisherman and the European Scientist' (2009) 18(4) Environmental Politics 557.

Jay S and others, 'Transboundary Dimensions of Marine Spatial Planning: Fostering Inter-Jurisdictional Relations and Governance' (2016a) 65 Mar Policy 85.

Jay S, Klenke T and Janßen H, 'Consensus and Variance in the Ecosystem Approach to Marine Spatial Planning: German Perspectives and Multi-Actor Implications' (2016b) 54 Land Use Policy 129.

Johnsen JP and Hersoug B, 'Local Empowerment Through the Creation of Coastal Space?' (2014) 19(2) Ecology and Society 60.

Jones P, Lieberknecht LM and Qiu W, 'Marine Spatial Planning in Reality: Introduction to Case Studies and Discussion of Findings' (2016) 71 Mar Policy 256.

Jordan A and Lenschow A, 'Policy Paper. Environmental Policy Integration: A State of the Art Review' (2010) 20(1) Environmental Policy and Governance 147.

Katsanevakis S and others, 'Ecosystem-Based Marine Spatial Management: Review of Concepts, Policies, Tools, and Critical Issues' (2011) 54 Ocean Coast Manag 80.

Kidd S, 'Rising to the Integration Ambitions of Marine Spatial Planning: Reflections from the Irish Sea' (2013) 39 Mar Policy 273.

Kidd S and Ellis G, 'From the Land to Sea and Back Again? Using Terrestrial Planning to Understand the Process of Marine Spatial Planning' (2012) 14(1) Journal of Environmental Policy and Planning 49.

Leslie $\mathrm{H}$ and others, 'Learning from Ecosystem-Based Management in Practice (2015) 43 Coast. Manag. 471.

Long RD, Charles A and Stephenson RL, 'Key Principles of Marine Ecosystem-Based Management' (2015) 57 Mar Policy 53.

Michałek M and Kruk-Dowgiałło L, 'Konsultacje społeczne jako element planowania ochrony obszarów natura 2000 na przykładzie zatoki puckiej, Inżynieria Ekologiczna' (2015) 42 Ecological Engineering 95.

Ostrom E, 'A General Framework for Analyzing Sustainability of Social-Ecological Systems' (2009) 325(5939) Science 419.

Portman ME, 'Marine Spatial Planning: Achieving and Evaluating Integration' (2011) 68(10) ICES Journal of Marine Science: Journal du Conseil 2191.

Qiu W and Jones P, 'The Emerging Policy Landscape for Marine Spatial Planning in Europe' (2013) 39 Mar Policy 182.

Ritchie H and Ellis G, 'A System That Works for the Sea? Exploring Stakeholder Engagement in Marine Spatial Planning' (2010) 53(6) Journal of Environmental Planning and Management 701.

Rodriguez NJI, 'A Comparative Analysis of Holistic Marine Management Regimes and Ecosystem Approach in Marine Spatial Planning in Developed Countries' (2017) 137 Ocean Coast Manag 185 . 
Santos C and others, 'How Sustainable is Sustainable Marine Spatial Planning? Part I Linking the Concepts' (2014) 49 Mar Policy 59.

Saunders F, Gilek M and Linke S, 'Knowledge for Environmental Governance: Probing Science-Policy Theory in the Cases of Eutrophication and Fisheries in the Baltic Sea' (2017) 6 Journal of Environmental Planning and Management 769.

Small N, Munday M and Durance I, 'The Challenge of Valuing Ecosystem Services That Have No Material Benefits' (2017) 44 Global Environmental Change 57.

Spruijt P and others, 'Roles of Scientists as Policy Advisers on Complex Issues: A Literature Review' (2014) 40 Environmental Science \& Policy 16.

Tafon VR, 'Taking power to sea: Towards a Post-Structuralist Discourse Theoretical Critique of Marine Spatial Planning' (2018) 36(2) Environment and Planning C: Politics and Space 258 .

Tynkkynen N and others, 'The Governance of the Mitigation of the Baltic Sea Eutrophication: Exploring the Challenges of the Formal Governing System' (2014) 43(1) Ambio 105.

Vigar G, 'Towards an Integrated Spatial Planning?' (2009) 17 (11) European Planning Studies 1571.

Zaucha J, 'Sea Basin Maritime Spatial Planning: A Case Study of the Baltic Sea Region and Poland' (2014) 5o Mar Policy 34.

\section{Other Sources}

Hassler B and others, 'BONUS BALTSPACE Deliverable 2.2: Ambitions and Realities in Baltic Sea Marine Spatial Planning and the Ecosystem Approach: Policy and Sector Coordination in Promotion of Regional Integration' (2017) <www.baltspace .eu> accessed 24 Sept 2018.

Jones P, Lieberknecht LM and Qiu W, 'Approaches for addressing conflicts in the MESMA case studies' (2013) Deliverable 6.2 of MESMA Work Package 6 (Governance) <www.homepages.ucl.ac.uk/ ucfwpej/pdf/MESMAD6-2.pdf> accessed 24 Nov 2017.

McCann and others, 'Identifying Marine Spatial Planning Gaps, Opportunities, and Partners: An Assessment' (Coastal Resources Center and Rhode Island Sea Grant College Program 2014).

Saunders and others, 'BONUS BALTSPACE Deliverable D2.4: MSP as a governance approach? Knowledge integration challenges in MSP in the Baltic Sea' (2017) < www.baltspace.eu> accessed 24 Sept 2018.

Zaucha and others, 'BONUS BALTSPACE Deliverable 2.1: Baseline-Mapping and Refined Case Study Design' (2016) < www.baltspace.eu> accessed 24 Nov 2017. 